\title{
Women's Roles in Household Economy in Medono Village, Boja, Kendal District
}

\author{
Fulia Aji Gustaman ${ }^{1 *}$, Gunawan ${ }^{2,}$ Ninuk Sholikhah Akhiroh ${ }^{3}$, Nurul Fatimah ${ }^{4}$ \\ Didi Pramono ${ }^{5,}$ Putri Sonia Purnawati ${ }^{6}$ M Ulin Nuha Saputra ${ }^{7}$ \\ 1, 2, 3, 4, 5,6,7 Department of Sociology and Anthropology, Universitas Negeri Semarang \\ *Corresponding author. Email: gustaman@mail.unnes.ac.id
}

\begin{abstract}
Natural resource management sustains to this day is agriculture. It remains the main source of making a living in rural communities despite its decreasing activity. According to the results of the 2018 Inter-Census Agricultural Survey (SUTAS), the number of farmers in Indonesia was 33487 806. Categorized by gender, there were 25.436.478 male farmers and 8.051.328 female farmers. Within the Central Java region, there were 5.264.264 farmers in which 4.013.514 were male and 1.250.750 were female. The difference between the number of male and female farmers is quite significant. This indicates that women seem to have small involvement in the agricultural business which is a vital source supporting the household. Whereas, in reality, women have significant roles in farm families. Therefore, this study aims to determine the extent of the role of women in agriculture as a source of sustaining the household economy. The research was conducted on the people of Medono Village, Boja Sub-district, Kendal District, with a qualitative research method. Data was collected through observation, interviews, and documentation.
\end{abstract}

Keywords: farmer, household, role, women.

\section{INTRODUCTION}

One of natural resource management activities that is considered as sustainable management is agriculture. Agriculture is still the main source of life for rural communities although the number is decreasing over time [1]. According to the results of the Inter-Census Agricultural Survey (SUTAS) in 2018, the number of farmers in Indonesia is 33487 806 people, consisting of $25,436,478$ male farmers and $8,051,328$ female farmers. In the Central Java region, there are 5,264,264 farmers consisting of 4,013,514 male farmers and 1,250,750 female farmers [1]. The ratio of the number of male and female farmers shows a significant figure. It indicates that women do not have involvement in agricultural bussines which is a source of support for the family's economy. Whereas in practice, in farming families, the role of family labor, especially women, has a significant share. In the aspect of labor, women have an important share. In agriculture, especially in food crop agriculture, the division of labor between men and women is very real. Men do works that require strength or muscle while women work for activities that require precision and tidiness, or works that take a lot of time [3].
The role of women in the household economy, especially in agriculture, cannot directly be calculated. This occurs because the agricultural production system is different from the industrial one. The agricultural production system is not structured and not based on capital-labor relations [3]. In agriculture, the role of family labor sources is very dominant, but its existence is not seen as a form of contribution. The role of women in agriculture is disguised and even ignored, even though in practice the female workforce in agriculture is very important, especially in the farm households that do not rely on agriculture only but also from other non-agricultural sectors. The nonagricultural sector which is the source of income for farmer households is the informal sector, such as construction laborers outside the village. This sector absorbs a lot of male labor, so that the role of men in agriculture has decreased. Meanwhile, the role of women increases because women partly take over of the responsibilities from men working in nonagricultural sectors, in managing agriculture.

The results of previous research show that agriculture in Medono Village is the main source for meeting household needs. However, the condition of the rainfed land with a slope of up to 45 degrees makes the agricultural business not produce maximum 
yields to be used as a source of meeting household needs. The agricultural effort that can be developed is a plantation system, especially for coffee and sugar palm. However, the plantation production system is still dominated by men. Therefore, there is a need for a study to determine the extent of women's roles in agricultural management, both in food agriculture and in plantations. Departing from the background already mentioned, this article will discuss the division of labor between men and women in agriculture in Medono Village.

\section{RESEARCH METHOD}

This study uses a qualitative method. Data collection is carried out through observation, interviews and reviewing documents related to the research focus. The research focus is about the division of labor in agriculture in Medono Village. The results of this study are used as a basis for mapping opportunities and potential resources that can provide opportunities for women to participate in managing agriculture. The results of the mapping became the basis for interventions to develop a model of economic empowerment based on women's activities.

\section{RESULTS AND DISCUSSION}

Medono Village is a village located in Boja Subdistrict, Kendal District. Medono Village is administratively divided into two hamlets, namely Krajan and Jambon. Krajan Hamlet is divided into 4 $R T$ (Neigborhood Association) and Jambon Hamlet is divided into $2 R T$. The people of Medono Village are mostly farmers. Based on the results of previous research, Medono Village has land for plantations of coffee, sugar palm, cloves, at the top of the village; rice fields in the flat area. The majority of existing land, both plantations and agriculture, are owned by villagers as private property. The ownership of land by the residents of Medono Village is divided into two, namely freehold land and land with usufruct / arable rights.

\subsection{Freehold land}

Land ownership is evidenced by a land ownership document from the village in the form of a Letter C. In addition to Letter C, the proof of land ownership is an SPPT or Tax Return Payable Letter. According to the agrarian law, Letter $\mathrm{C}$ as the evidence or documents of land ownership for residents in Medono Village is still recognized by the state but the legal force is not as strong as the certificate.
Meanwhile, the SPPT itself does not legally have binding legal force and shows the right to land ownership status because basically the SPPT functions as a tax object bill document ( for land and buildings).

\subsection{Right to Use Land / Arable Land}

This kind of land is land in the forest on the slopes of Mount Ungaran which is used by some residents on the northern slopes of Mount Ungaran including Medono Village residents to cultivate plantation commodities, especially coffee. Legally, the ownership status of the arable land belongs to Perum Perhutani Kesatuan Pengelola Hutan (Indonesian Forest Management Agency), of North Kedu area. Nevertheless, the people of Medono Village are allowed to cultivate the land by the permission of Perhutani.

Not too many villagers work on Perhutani's land. This is because the land owned by Perhutani is located in a forest area, causing a difficult access to it. Moreover, the majority of Medono Village residents already have private land so they prefer to work on their own private land rather than cultivate Perhutani's land.

The process of utilizing Perhutani's land in general does not have any specific rules, but residents who cultivate the land are only allowed to use the land and are prohibited from logging and destroying existing trees / plants. Residents who cultivate Perhutani's land are not charged a much rental fee, but usually give "tribute" in the form of money in the nominal value of Rp. 50,000 , Rp. 100,000 or with the yields of the harvest in the form of coffee or cloves to the Perhutani "officials". The giving of "tribute" to Perhutani is carried out once a year during the harvest season for plantation commodities.

The utilization of the arable land belonging to Perhutani brings benefits to both the tenant residents and Perhutani. For residents who work on the land, they get benefits in the form of increased income from commodities planted in the land, while for Perhutani officials, they get benefits in the form of being helped in caring for and preserving the land.

Coffee is the main agricultural commodity planted by the people of Medono Village in addition to other agricultural commodities such as sugar palm, cloves, cardamom, rice, and sengon wood. The type of coffee grown is the robusta with two varieties, namely the robusta kipas and the robusta mayung. The choice of planting robusta coffee is because the robusta type is suitable with the soil type and the weather in Medono Village which is not too cold. The robusta 
kipas is the first coffee variety cultivated by the residents of Medono Village. This variety has various weaknesses such as does not bear much fruit, has a small fruit size, and takes up a lot of space due to the plant size, so that currently residents of Medono Village, especially Jambon Hamlet, are starting to do replacement of the robusta kipas to the robusta mayung originating from the Temanggung area. This is because the robusta mayung has several advantages such as bears more fruit, has a larger fruit size and plant size that does not take up much space, which make the farmers get a bigger profit.

The fact that the majority of the people in Medono Village work as farmers encourages the formation of a farmer group as a forum for farmers in the village to build their solidarity and capacity. The farmer group is divided into two groups since there are two hamlets in Medono Village, namely, Krajan and Jambon. However, along the time, the farmer group that currently still exists is the Jambon Hamlet's. The farmer group in Jambon has approximately 20 members with various agricultural professions. It is worthy to say that all the members are male. The role of men as workers in the public sector is very visible here. This is evidenced by the fact that almost all farming activities, especially in managing coffee plantations, are carried out by men, from picking, processing to selling. Meanwhile, women have more roles as domestic workers, that is, to prepare various needs in the household.

Sugar palm is a daily commodity for the people of Medono Village besides coffee. Almost every day the villagers make palm sugar. In a day, they are able to make about $3 \mathrm{~kg}$ to $7 \mathrm{~kg}$ of palm sugar, depending on the sap obtained. Sugar palm farmers in Krajan Hamlet usually go for tapping sap in the garden at 05.30 WIB (Western Indonesia Time), then return home at around 08.00 WIB. The tapping activity is usually done by men only. Meanwhile, women will later cook palm juice (called sap) to be proceeded into palm sugar. The women usually start to boil sap at 09.00 WIB for about 6 hours. After the sap thickens, it will be molded using coconut shell as the mold. After the molding process is complete, the sap is allowed to dry in the mold to be palm sugar. Women in the village of Medono usually sell the palm sugar to traders and the money they get is sufficient to meet their daily needs.

Based on the data above, the role of women who work in the agricultural sector in Medono Village is only limited to helping their husbands. Women get more roles as workers in the domestic sector, namely preparing various needs in the household. While in agriculture, women help their husbands in the production process such as drying coffee or processing sugar palm. Women's access and control in managing agricultural resources is still limited to a production instrument. Women do not have the opportunity to work and cultivate plantation land. With such a reality, of course, household income only depends on the working husband, so that the burden of fulfilling family needs is only fulfilled by the work of men. Meanwhile, women's participation in the management of existing economic resources is still at the domestic level.

\section{CONCLUSION}

The main source of income for the Medono community from the agricultural sector is divided into two, namely coffee as a seasonal agricultural commodity and sugar palm as a daily agricultural commodity. Division of labor system between men and women in agriculture in Medono Village is still not balanced. The role of men as workers in the public sector is very visible in managing agriculture and plantations. This is evidenced by the fact that almost all farming and gardening activities, especially in coffee processing, are carried out by men, while women have more roles as domestic workers. From this reality, it can be concluded that the level of women's participation in managing economic resources is still limited.

\section{REFERENCES}

[1] cnbc Indonesia.com (2019). Krisis Petani di RI Apakah Benar-benar Terjadi. https://www.cnbcindonesia.com/news/20191114 163245-4-115342/krisis-petani-di-ri-apakahbenar-benar-terjadi diakses 14 Maret 2020, 20:20

[2] Biro Pusat Statistik, (2018) Survey Pertanian Antar Sensus.

[3] Y. H. Bertham, D. W. Ganefianti, and A. Andani, "Peranan Perempuan Dalam Perekonomian Keluarga Dengan Memanfaatkan Sumberdaya Pertanian," Jurnal AGRISEP, vol. 10, no. 1, pp. 138-153, 2011.

[4] Ploeg, Jan Douwe Van Der (2019), Petani dan Seni Bertani, Maklumat Chayanovian. (Terjemahan Ciptaningrat Larastiti), Insist Press, Yogyakarta.

[5] J. Salaa (2015)“Peran Ganda Ibu Rumah Tangga Dalam Meningkatkan Ekonomi Keluarga Di Desa Tarohan Kecamatan Beo Kabupaten Kepulauan Talaud," Jurnal Holistik, no. 15, pp. $1-16$. 
[6] W. Nugraheni. S (2012) "Peran Dan Potensi Wanita Dalam Pemenuhan Kebutuhan Ekonomi Keluarga Nelayan," JESS (Journal Education Social Study., vol. 1, no. 2.

[7] S. Widodo (2012) "Peran Perempuan Dalam Sistem Nafkah Rumah Tangga Nelayan," Seminar Nasional Kedaulatan Pangan dan Energi, Fakultas Pertanian, Universitas Trunojoyo Maduran.

[8] R. Yulida (2012) "Kontribusi Usaha Tani Lahan Pekarangan Terhadap Ekonomi Rumah Tangga Petani Di Kecamatan Kerinci Kabupaten Pelalawan," Indonesian Journal of Agricultural. Economics., vol. 3, no. 2, pp. 135-154.

[9] Murit (2010) "Dari Doro Ke Raki: Ekonomi Gender Dan Transformasi Sosial Pertanian Orang Galela. Komunitas International Jurnal of Indonesian Society and Culture vol. 2, no. 2, pp. 125-134.

[10] A. Luthfi, (2013) “Akses Dan Kontrol Perempuan Petani Penggarap Pada Lahan Pertanian Ptpn Ix Kebun Merbuh," Komunitas International Jurnal of Indonesian Society and Culture., vol. 2, no. 2, pp. 74-83. 